\title{
Ginsenoside Rg3 protects mouse leydig cells against triptolide by downregulation of miR-26a
}

This article was published in the following Dove Press journal:

Drug Design, Development and Therapy

\author{
Haiyan Liang' \\ Suwei Zhang ${ }^{2}$ \\ Zhiling $\mathrm{Li}^{\prime}$
}

'Reproductive Center, The First Affiliated Hospital of Shantou University Medical College, Shantou University, Shantou, Guangdong 5I503I, People's Republic of China; ${ }^{2}$ Department of Clinical

Laboratory Medicine, Shantou Central Hospital, Shantou, Guangdong 5I503I, People's Republic of China
Correspondence: Zhiling Li

Reproductive Center, The First Affiliated Hospital of Shantou University Medical

College, Shantou University, No. 57

Changping Road, Shantou 51503I,

Guangdong, People's Republic of China

$\mathrm{Tel}+86075488258290$

Email zhilingli@yandex.com
Background: Ginsenoside $\operatorname{Rg} 3$ has been reported to exert protection function on germ cells. However, the mechanisms by which Rg3 regulates apoptosis in mouse Leydig cells remain unclear. In addition, triptolide (TP) has been reported to induce infertility in male rats. Thus, this study aimed to investigate the protective effect of $\mathrm{Rg} 3$ against TP-induced toxicity in MLTC-1 cells.

Methods: CCK-8, immunofluorescence assay, Western blotting and flow cytometry were used to detect cell proliferation and cell apoptosis, respectively. In addition, the dual luciferase reporter system assay was used to detect the interaction between miR-26a and GSK3 $\beta$ in MLTC-1 cells.

Results: TP significantly inhibited the proliferation of MLTC-1 cells, while the inhibitory effect of TP was reversed by Rg3. In addition, TP markedly induced apoptosis in MLTC-1 cells via increasing the expressions of Bax, active caspase 3, Cyto $\mathrm{c}$ and active caspase 9, and decreasing the level of Bcl-2. However, Rg3 alleviated TP-induced apoptosis of MLTC-1 cells. Moreover, the level of miR-26a was obviously downregulated by $\operatorname{Rg} 3$ treatment. The protective effect of Rg3 against TP-induced toxicity in MLTC-1 cells was abolished by miR26a upregulation. Meanwhile, dual-luciferase assay showed GSK3 $\beta$ was the direct target of miR-26a in MLTC-1 cells. Overexpression of miR-26a markedly decreased the level of GSK3 $\beta$. As expected, upregulation of miR-26a could abrogate the protective effects of $\mathrm{Rg} 3$ against TP-induced cytotoxicity via inhibiting the expression of GSK3 $\beta$.

Conclusion: These results indicated that $\mathrm{Rg} 3$ could protect MLTC-1 against TP by downregulation of miR-26a. Therefore, $\mathrm{Rg} 3$ might serve as a potential agent for the treatment of male hypogonadism.

Keywords: ginsenoside $\operatorname{Rg} 3$, male hypogonadism, triptolide, MLTC-1 cell, apoptosis

\section{Introduction}

Male hypogonadism is usually related to impotence, infertility or a reduction in spermatogenesis. ${ }^{1}$ Testosterone, a vital hormone, is necessary for spermiogenesis and maintenance of secondary sexual functions in men. ${ }^{2}$ In the recent years, about $6 \%$ of males were attacked by male hypogonadism. ${ }^{3}$ The deficiency of serum testosterone in males not only leads to male sexual dysfunction, but also induces other diseases, such as obesity, skeletal muscle wasting and diabetes. ${ }^{4-7}$ Testosterone is generated in Leydig cells, while with the age increase, the number of Leydig cells will reduce. ${ }^{8}$ The number of Leydig cells are closely associated with male reproductive system and sexual function. ${ }^{9}$ Therefore, improving the male sperm motility and hypogonadism is beneficial to improving sexual function, fertility and quality of life of males. 
Panax ginseng is a common Chinese herbal medicine in the Orient. ${ }^{10}$ Ginsenosides is one of the pharmacologically active compounds in the Ginseng, which could regulate multiple metabolic pathways. ${ }^{10,11}$ Ginsenoside $R g 3$ is the most active compound of ginsenosides. ${ }^{12} \mathrm{Rg} 3$ exerts a variety of pharmacological properties including anti-tumor, anti-inflammation, treatment of diabetes, anti-pruritic effects. ${ }^{13-16}$ In addition, $\operatorname{Rg} 3$ could enhance erectile function in diabetic rats against streptozotocin. ${ }^{17}$ Meanwhile, Rg3 could improve endometrial lesions by promoting apoptosis in ectopic endometrial cells. ${ }^{18}$ However, the effect of Rg3 in leydig cells remains unclear.

Triptolide (TP), a diterpene triepoxide extracted from a Chinese medicinal herb Tripterygium wilfordii, is a posttesticular male contraceptive agent. ${ }^{19}$ Huang et al demonstrated that TP could produce cell toxicity on the male reproductive system in rats by increasing the deformity rate of sperm. ${ }^{20} \mathrm{TP}$ has been reported to induce infertility in male rats. ${ }^{21}$ In addition, the longer duration of TP treatment could influence the spermatogenesis. ${ }^{19}$

Glycogen synthase kinase-3 $\beta$ (GSK3 $\beta$ ) is a serinethreonine kinase, which involves in some cellular signaling pathways. ${ }^{22}$ GSK $3 \beta$ signaling has been implicated in cardiac disease and human cancers. ${ }^{23}$ However, little is known about the role of GSK3 $\beta$ in spermiogenesis. In addition, it has been reported that male hypogonadism was associated with microRNAs (miRNAs) ${ }^{24}$ Evidences indicated that microRNA-26a (miR-26a) plays important roles in tumor cells and neural stem cells; however, the function of miR-26a during male hypogonadism remains unclear. $^{23,25}$ Although previous studies have reported that Rg3 had multiple pharmacological functions, the mechanisms by which $\mathrm{Rg} 3$ regulates the proliferation and apoptosis in MLTC-1 cells against TP remain unclear. Therefore, this study aimed to investigate the protective effect of $\mathrm{Rg} 3$ against TP-induced toxicity in MLTC-1 cells.

\section{Materials and methods}

\section{Cell culture and cell transfection}

The mouse Leydig MLTC-1 cell line was obtained from American Type Culture Collection (ATCC, Rockville, MD, USA). The cells were cultured in RPMI-1640 medium with $10 \%$ fetal bovine serum (Thermo Fisher Scientific, Waltham, MA, USA), penicillin $(100 \mathrm{U} / \mathrm{mL}$, Sigma Aldrich, St. Louis, MO, USA) and streptomycin $\left(100 \mu \mathrm{g} / \mathrm{mL}\right.$, Sigma Aldrich) at $37^{\circ} \mathrm{C}$ with $5 \% \mathrm{CO}_{2}$. $\mathrm{Rg} 3$ was purchased from Sigma Aldrich.
MLTC- 1 cells $\left(4 \times 10^{5}\right.$ cells per well) were plated into 6-well plates overnight at $37^{\circ} \mathrm{C}$. Then, miR-26a mimics were transfected into cells for $24 \mathrm{hrs}$ at $37^{\circ} \mathrm{C}$ using Lipofectamine 2000 reagent according to the manufacturer's instructions. MiR-26a mimics were purchased from GenePharma (Shanghai, China). GSK3 $\beta$ inhibitor 1 was provided by MedChemExpress (Monmouth Junction, NJ, USA).

\section{CCK-8 assay of cell viability}

Cell Counting Kit-8 (CCK-8, Sigma Aldrich) was used to assess the cell viability according to the specification. MLTC- 1 cells $\left(5 \times 10^{3}\right.$ cells per well) were plated into 96well plates overnight at $37^{\circ} \mathrm{C}$. After that, cells were treated with TP $(0,40,80,120,160$ or $200 \mathrm{nM})$, or $\operatorname{Rg} 3(0,5,10$, 20,40 or $80 \mu \mathrm{M}$ ) for $24 \mathrm{hrs}$ at $37^{\circ} \mathrm{C}$. In addition, cells were treated with TP $(120 \mathrm{nM})$ and $\operatorname{Rg} 3(0,5,10,20$ or $40 \mu \mathrm{M})$ for $24 \mathrm{hrs}$ at $37^{\circ} \mathrm{C}$. After $2 \mathrm{hrs}$ of incubation with CCK-8 solution $(10 \mu \mathrm{L})$, microplate reader (BioRad, Hercules, CA, USA) was applied to detect the absorbance of cells at a wavelength of $450 \mathrm{~nm}$.

\section{Immunofluorescence}

MLTC-1 cells $\left(5 \times 10^{4}\right.$ cells per well) were plated into 24 well plates overnight at $37^{\circ} \mathrm{C}$. The cells were fixed in methanol at room temperature for 10 mins. Then, cells were permeabilized in Triton X-100 and washed 3 times with PBS. The samples were then incubated with anti-Ki 67 (Abcam Cambridge, MA, USA), anti-DAPI (Abcam) for $1 \mathrm{hr}$. After that, cells were subsequently treated with goat anti-ribbit IgG $\mathrm{H} \& \mathrm{~L}$ (Abcam) for $1 \mathrm{hr}$ at $37^{\circ} \mathrm{C}$. Later on, the stained cells were observed by confocal microscopy (Olympus CX23, Tokyo, Japan).

\section{Western blot analysis}

Equal amounts of protein ( $40 \mu \mathrm{g}$ per lane) were separated by SDS-PAGE gels. Then, proteins were transferred onto PVDF membranes (Thermo Fisher Scientific). The PVDF membranes were blocked with 5\% skim milk and incubated with the corresponding primary antibodies overnight at $4^{\circ} \mathrm{C}$. Anti-Bax (Abcam, 1:1000, ab32503), anti-Bcl-2 (Abcam, 1:1000, ab32124), anti-active caspase 3 (Abcam, 1:1000, ab2302), anti-Cyto c (Abcam, 1:1000, ab133504), anti-GSK3 $\beta$ (Abcam, 1:1000, ab32391), anti-active caspase 9 (Abcam, 1:1000, ab32539), anti- $\beta$-actin (Abcam, 1:1000, ab8227). After that, the membranes were washed four times with TBST (5 mins each) and incubated with secondary antibodies for 50 mins. Later on, the ECL 
reagent (GE Healthcare, Buckinghamshire, UK) was applied for visualization. ChemiDoc ${ }^{\text {TM }}$ XRS+ imaging system (Bio-Rad, Hercules, CA, USA) was used to capture the blots.

Flow cytometric analysis of cell apoptosis MLTC-1 cells were centrifuged and trypsinized at $4{ }^{\circ} \mathrm{C}$. Then, cells were washed twice with pre-cold PBS and resuspended in binding buffer $(500 \mu \mathrm{L}) .5 \mu \mathrm{L}$ of Annexin V-FITC and $5 \mu \mathrm{L}$ of PI reagents were added into each sample for 10 mins in the dark. Gallios Flow Cytometer (Beckman Coulter, Brea, CA, USA) was applied to analyze the apoptotic cells using the FlowJo software (Ashland, OR, USA).

\section{Real-time $\mathrm{qPCR}$}

Total RNA was extracted from MLTC-1 cells according to the manufacturer's specification using a Trizol kit (Thermo Fisher Scientific). Then, cDNA Reverse Transcription Kit (Thermo Fisher Scientific) was used to synthesize cDNA. After that, PCR was performed by using SYBR Green master mix kit (Thermo Fisher Scientific). The qPCR conditions were as follows: $94^{\circ} \mathrm{C}$ for $5 \mathrm{mins}$; and 35 cycles of $95^{\circ} \mathrm{C}$ for $30 \mathrm{~s}, 60^{\circ} \mathrm{C}$ for 30 $\mathrm{s}$ and $75^{\circ} \mathrm{C}$ for 45 mins. The sequences of primers are as follows: miR-34a: Forward: 5'-ACAGTCTCATGCCAG GAAAGC-3', Reverse: 5'-GCACATTGATGATGCACA GGC-3'; miR-15a: Forward: 5'-GCTAGCAGCACATAA TGGTTTGTG-3', Reverse: 5'-GTGCAGGGTCCGAGG TATTC-3'; miR-184: Forward: 5'-TACGACTATGTGAC CTGCCTG-3', Reverse: 5'- TGGTTCAACTCTCCTTT CCA-3'; miR-130a Forward: 5'-GGGGTACCGCTTACC CACATCATA-3', Reverse: 5'-GAAGATCTTACCACC ATGGATCGTC-3'; miR-26a: Forward: 5'- ACACTCC AGCTGGGTTCAAGTAATCCAGGA-3', Reverse: 5'TGGTGTCGTGGAGTCG-3'; GSK3 $\beta$ : Forward: 5'-CAA AGCAGCTGGTCCGAGG-3', Reverse:5'-TCCACCAA CTGATCCACACCAC-3', U6: Forward: 5'- CGCTT CGGCAGCACATATAC-3', Reverse: 5'-AAATATGGAA CGCTTCACGA-3'. The relative levels of miR-34a, miR15a, miR-184, miR-130a, miR-26a and GSK3B were normalized to the level of U6. The $2^{-\Delta \Delta \mathrm{Ct}}$ method was used to analyze the data. ${ }^{26}$

\section{Luciferase reporter assay}

MLTC-1 cells were plated onto the 96 -well plates at $37^{\circ} \mathrm{C}$ and cultured to reach $70 \%$ confluence. The wild-type and mutant-type human GSK3 $\beta$-3' UTR were constructed, and cloned into the pMIR-REPORT Luciferase vector (Promega, Madison, Wisconsin, USA). The designed miR-26a mimics control was then used to co-transfect MLTC-1 cells together with the corresponding plasmids (Wide type GSK3 $\beta$ or mutant GSK3 $\beta$ ) using Lipofectamine 2000 for 48 hrs. The luciferase report activity was measured with the Dual Luciferase reporter 1000 Assay System (Promega). The data were normalized to the rellina luciferase activity of control group.

\section{Statistical analysis}

All experiments were performed at least three independent experiments and all data were expressed as the mean $\pm \mathrm{SD}$. The data were conducted with GraphPad Prism version 7 (GraphPad Software, CA, USA.). One-way ANOVA followed by Dunnett's test was used to analyze the difference between groups with $P<0.05$ being regarded as indicating a statistically significant difference $(* P<0.05, * * P<0.01)$.

\section{Results}

\section{Rg3 attenuated TP-induced cytotoxicity in MLTC-I cells}

The chemical structure of $\operatorname{Rg} 3$ was indicated in Figure 1A. CCK-8 assay was used to determine the effects of Rg3 or TP on the viability of MLTC-1 cells. As shown in Figure $1 \mathrm{~B}$, TP dose-dependently inhibited the proliferation of MLTC-1 cells. $120 \mathrm{nM}$ TP induced about $60 \%$ cell growth inhibition, which was utilized in the following experiments. In addition, $80 \mu \mathrm{M} \operatorname{Rg} 3$ significantly inhibited the proliferation of MLTC-1 cells, whereas 5, 10, 20 or $40 \mu \mathrm{M}$ Rg3 had no obvious inhibitory effects on MLTC-1 cells (Figure 1C). Furthermore, TP inhibited the proliferation of MLTC-1 cells, which were reversed the most by $20 \mu \mathrm{M}$ Rg3 treatment (Figure 1D). Therefore, $20 \mu \mathrm{M}$ Rg3 were utilized in the following experiments. Similarly, the immunofluorescence assay data indicated that $\operatorname{Rg} 3$ exhibited notably protective effects against TP-induced cytotoxicity (Figure $1 \mathrm{E}$ and $\mathrm{F}$ ). These results indicated that $\mathrm{Rg} 3$ could attenuate TP-induced cytotoxicity in MLTC-1 cells.

\section{$\mathrm{Rg} 3$ reversed TP-induced apoptosis of MLTC-I cells}

To further investigate the effects of $\mathrm{Rg} 3$ in TP-treated MLTC-1 cells, flow cytometry was used. As illustrated in Figure 2A and B, TP markedly induced apoptosis of MLTC1 cells, which was reversed by $\operatorname{Rg} 3$ treatment. In addition, Western blotting was used to measure the expressions of 

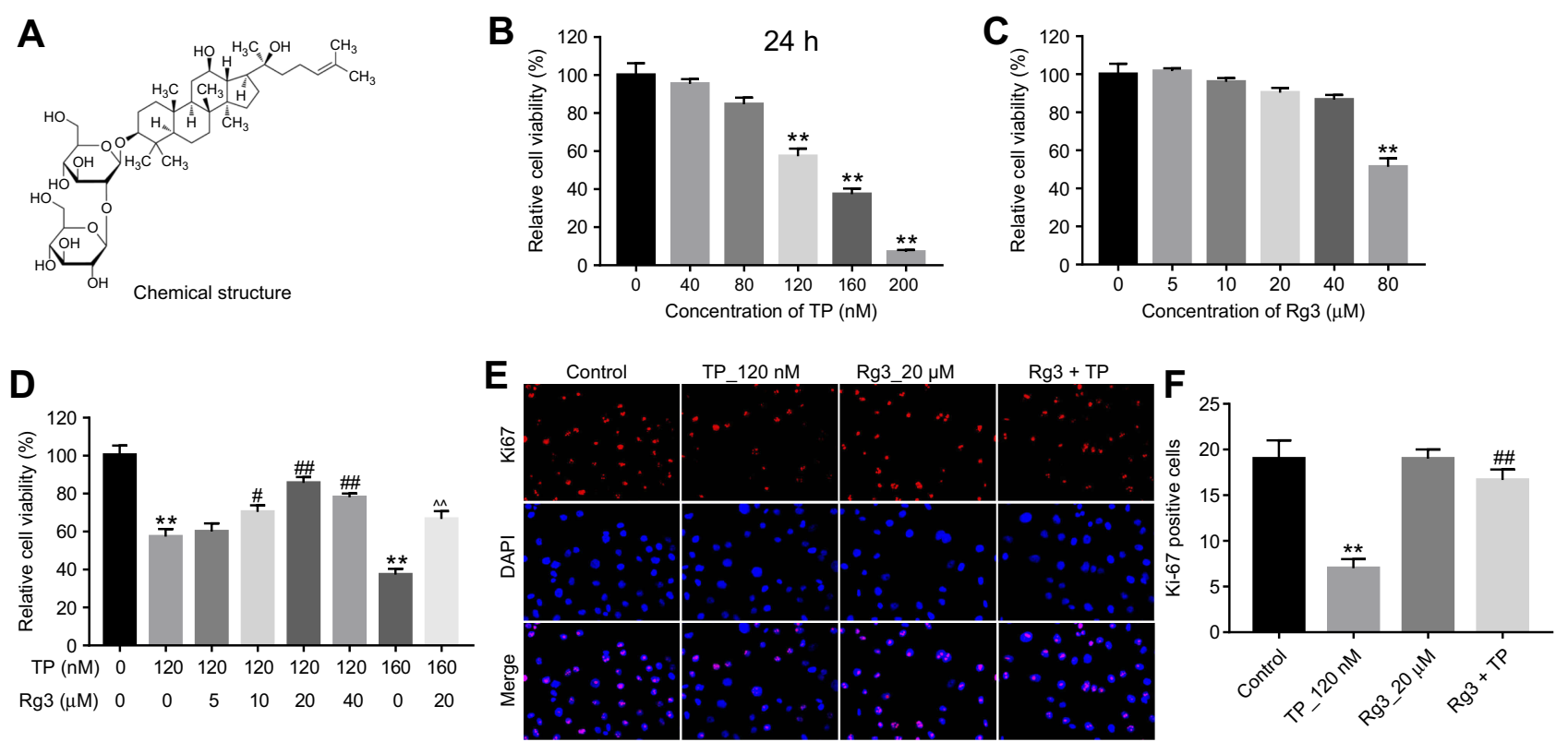

Figure I Rg3 attenuated TP-induced cytotoxicity in MLTC-I cells. (A) The chemical structure of Rg3. (B) CCK-8 assay was used to detect the viability of MLTC-I cells. MLTC-I cells were treated with TP $(0,40,80,120,160,200 \mathrm{nM})$ for 24 hrs. (C) MLTC-I cells were treated with Rg3 $(0,5,10,20,40,80 \mu \mathrm{M})$ for $24 \mathrm{hrs}$. (D) MLTC-I cells were treated with TP (I20 nM) and Rg3 (0, 5, 10, 20, $40 \mu \mathrm{M})$ for $24 \mathrm{hrs}$. (E and F) MLTC-I cells were treated with I20 nM TP or/and $20 \mu \mathrm{M}$ Rg3 for 24 hrs. Relative fluorescence expression levels were quantified by Ki67 and DAPI staining. ${ }^{* * P}<0.01$ compared with control group; ${ }^{\# P<0.05, ~}{ }^{\# P<0.01}$ compared with TP_120 nM group; ${ }^{\wedge} \mathrm{P}<0.01$ compared with TP_I60 nM group.
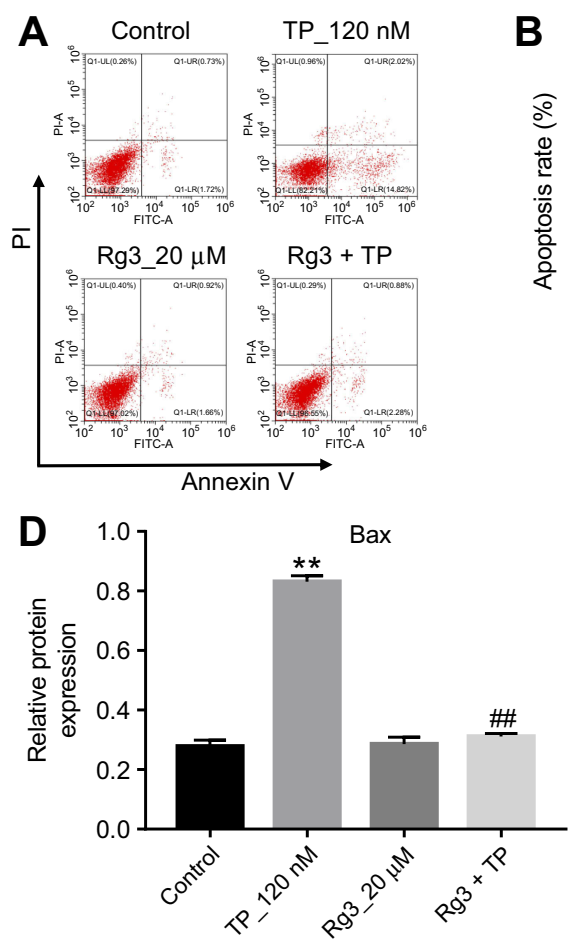
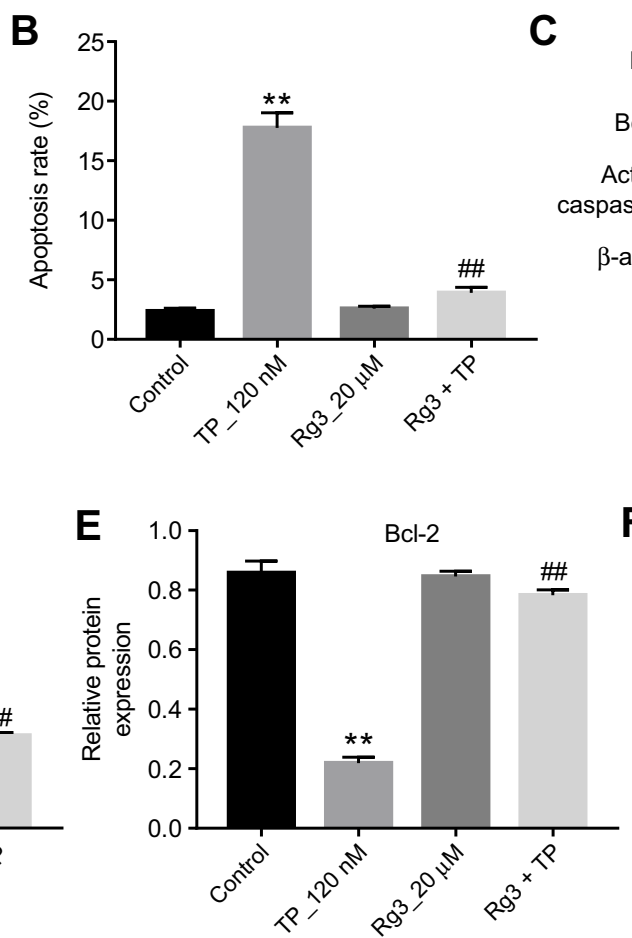
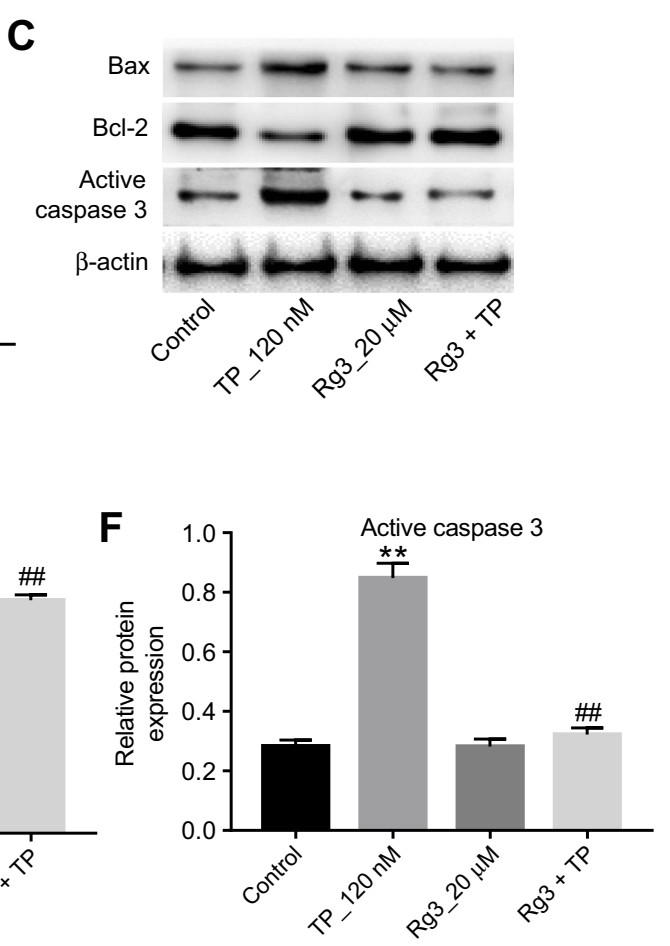

Figure $2 \mathrm{Rg} 3$ reversed TP-induced apoptosis in MLTC-I cells. MLTC-I cells were treated with $120 \mathrm{nM}$ TP or/and $20 \mu \mathrm{M}$ Rg3 for 24 hrs. (A and B) Apoptotic cells were measured with Annexin V and PI double staining. (C) Expression levels of Bax, Bcl-2 and active caspase 3 in MLTC-I cells were detected with Western blotting. $\boldsymbol{\beta}$-actin was used as an internal control. (D-F) The relative expressions of Bax, Bcl-2 and active caspase 3 were quantified via normalization to $\boldsymbol{\beta}$-actin. $* * P<0.0 \mathrm{I}$ compared with control group; ${ }^{\#} \mathrm{P}<0.01$ compared with TP_I20 nM group. 
apoptosis-related proteins $\mathrm{Bcl}-2$, Bax and active caspase 3 . As indicated Figure 2C, D, E and F, TP increased the levels of Bax and active caspase 3 and increased the expression of Bcl-2 in cells, while these effects were significantly reversed by $\mathrm{Rg} 3$ treatment. These data suggested that Rg3 could reverse TP-induced apoptosis of MLTC-1 cells.

\section{Overexpression of miR-26a reversed the protective effects of $\mathrm{Rg} 3$ against \\ TP-induced cytotoxicity in MLTC-I cells}

The proliferation of Leydig cells could maintain spermatogenesis in adult male mice. ${ }^{27}$ In addition, the spermatogenesis occurs mainly in Leydig cells. ${ }^{27}$ Previous studies demonstrated that miR-34a, miR-15a, miR-184, miR-130a and miR-26a have been shown to be associated with spermatogenesis. $^{24,28-33}$ Thus, qRT-PCR was used to detect the levels of these miRNAs in MLTC-1 cells. As demonstrated in Figure 3A, the level of miR-26a was significantly downregulated by $\mathrm{Rg} 3$ in MLTC-1 cells. However, the expression of miR-26a was slightly upregulated in TP-induced MLTC-1 cells (Figure 3B).

As shown in Figure 3C, the level of miR-26a was markedly increased in miR-26a mimics group, compared with control group. In addition, the protective effects of $\mathrm{Rg} 3$ against TP-induced cytotoxicity in MLTC-1 cells were reversed following transfection with miR-26a mimics (Figure 3D). Moreover, the protective effects of $\mathrm{Rg} 3$ against TP-induced apoptosis in MLTC-1 cells were reversed by miR-26a mimics as well (Figure 3E and F). All these results indicated that overexpression of miR-26a reversed the protective effects of Rg3 against TP-induced cytotoxicity in MLTC-1 cells.

\section{GSK $3 \beta$ was a direct target of miR-26a}

The mechanism by which miRNAs exhibit corresponding effects by binding to the $3^{\prime}$ UTR of target gene has been shown. ${ }^{34}$ Three online bioinformatics tools, TargetScan,
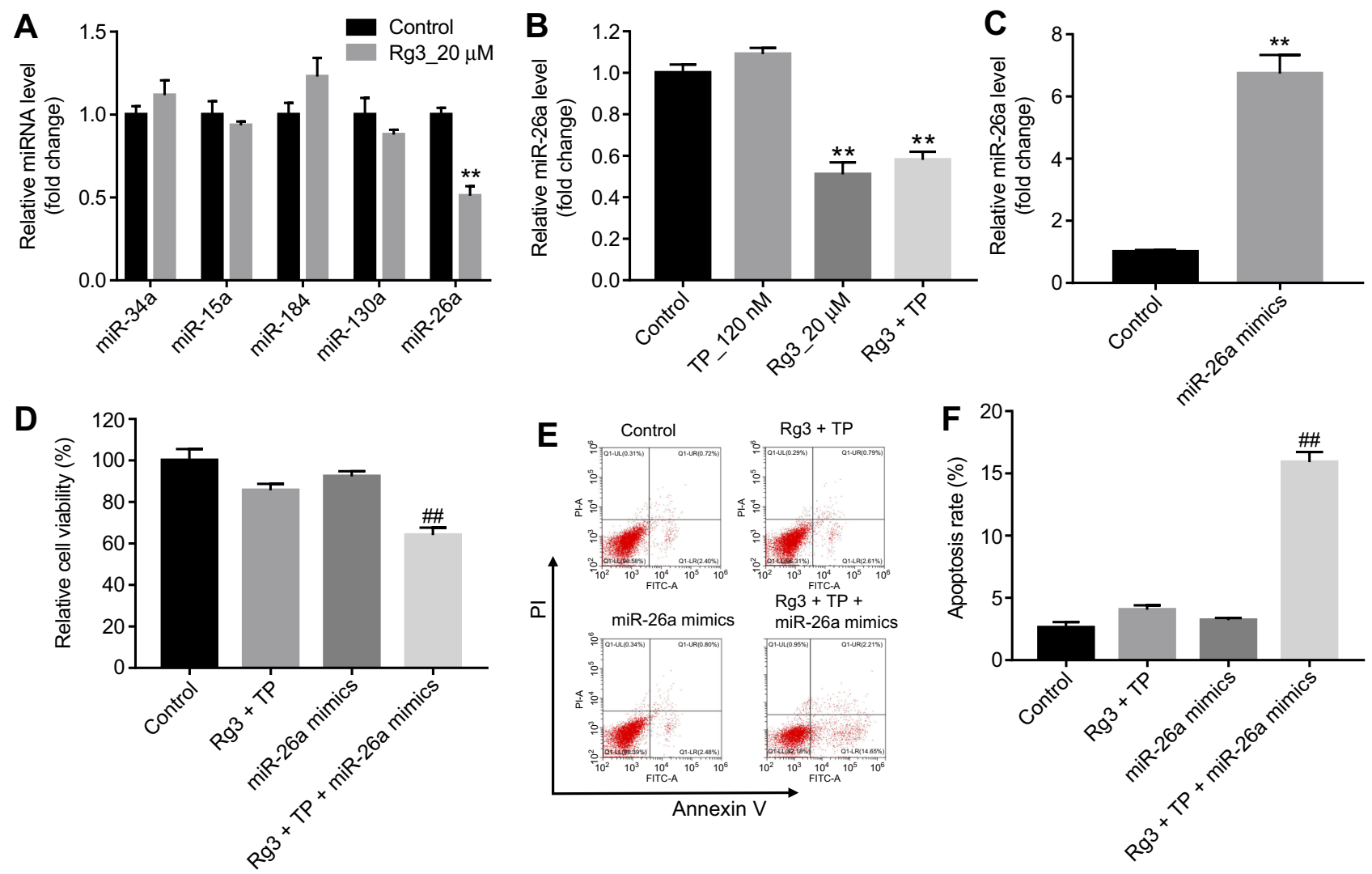

Figure 3 Overexpression of miR-26a reversed the protective effects of Rg3 against TP-induced cytotoxicity in MLTC-I cells. (A) MLTC-I cells were treated with $20 \mu M$ Rg3 for 24 hrs. Relative expressions of miR-34a, miR-I5a, miR-I84, miR-I30a and miR-26a in MLTC-I cells were detected by qRT-PCR. (B) MLTC-I cells were treated with I20 nM TP or/and $20 \mu \mathrm{M}$ for $24 \mathrm{hrs}$. Relative expression of miR-26a in MLTC-I cells was detected by qRT-PCR. (C) MLTC-I cells were transfected with I0 nM miR-26a mimics for 24 hrs. Relative expression of miR-26a in MLTC-I cells was detected by qRT-PCR. (D) MLTC-I cells were treated with I0 nM miR-26a mimics, I20 nM TP plus $20 \mu M$ $\mathrm{Rg} 3$ or triple treatment for 24 hrs. CCK-8 assay was used to detect the viability of MLTC-I cells. (E and F) MLTC-I cells were treated with 0 nM miR-26a mimics, I20 nM

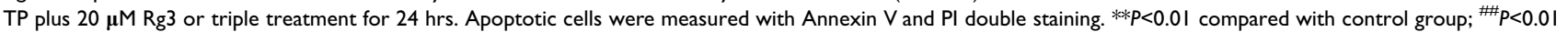
compared with $\mathrm{Rg} 3+\mathrm{TP}$ group. 
miRDB, or microRNA were used to predict the downstream targets of miR-26a. The results showed that GSK3 $\beta$ was a potential target of miR-26a (Figure 4A and B). In addition, the luciferase assay data indicated that reduced luciferase activity was observed in MLTC-1 cells following transfection with psiCHECK-2-GSK3 $\beta$-WT and miR-26a mimics (Figure 4C). Moreover, qRT-PCR analysis confirmed that the level of GSK3 $\beta$ was markedly decreased following transfection with miR-26a mimics (Figure 4D). These data revealed that GSK3 $\beta$ is a downstream target of miR-26a.

\section{Overexpression of miR-26a reversed the protective effects of $\mathrm{Rg} 3$ against TP- induced cytotoxicity via targeting GSK3 $\beta$}

In order to detect the mechanism by which miR-26a regulated GSK3 $\beta$ in MLTC-1 cells, Western blot was applied. As indicated in Figure $5 \mathrm{~A}$ and $\mathrm{B}$, the level of GSK $3 \beta$ was significantly increased by $\mathrm{Rg} 3$ treatment, whereas $\mathrm{Rg} 3$ induced GSK3 $\beta$ upregulation was completely inhibited by GSK3 $\beta$ selective inhibitor. In addition, Western blotting data indicated that TP markedly induced the upregulation of Cyto c and active caspase 9 and notably downregulation of GSK $3 \beta$, which were significantly reversed by $\operatorname{Rg} 3$ (Figure $5 \mathrm{C}, \mathrm{D}$, $\mathrm{E}$ and $\mathrm{F}$ ). However, the protective effect of $\mathrm{Rg} 3$ was significantly reversed following transfection with miR-26a mimics (Figure 5C, D, E and F). These results suggested that overexpression of miR-26a could attenuate the protective effects of $\mathrm{Rg} 3$ against TP-induced cytotoxicity via targeting GSK3 $\beta$.

\section{Discussion}

Leydig cells play important roles in spermatogenesis, because the synthesis of testosterone and spermatogenesis mainly occurs in Leydig cells. ${ }^{35}$ Previous study found that TP could lead to male infertility. ${ }^{36}$ In addition, TP could induce reproduction toxicity via influencing spermatogenesis

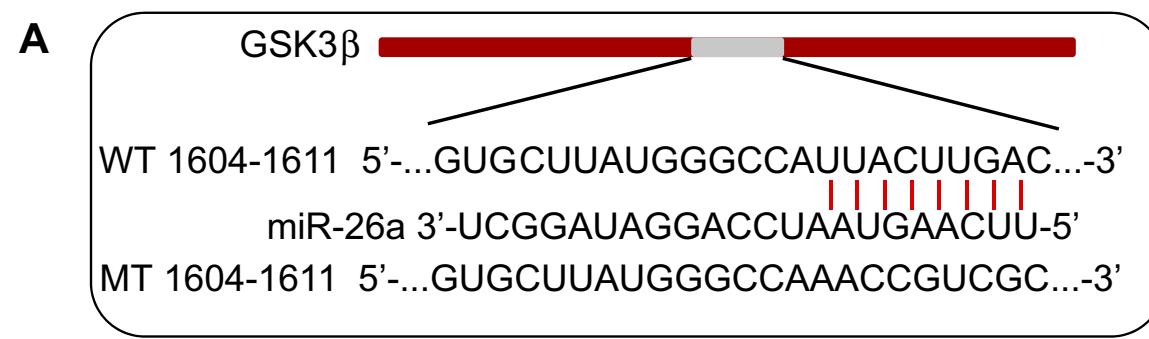

B
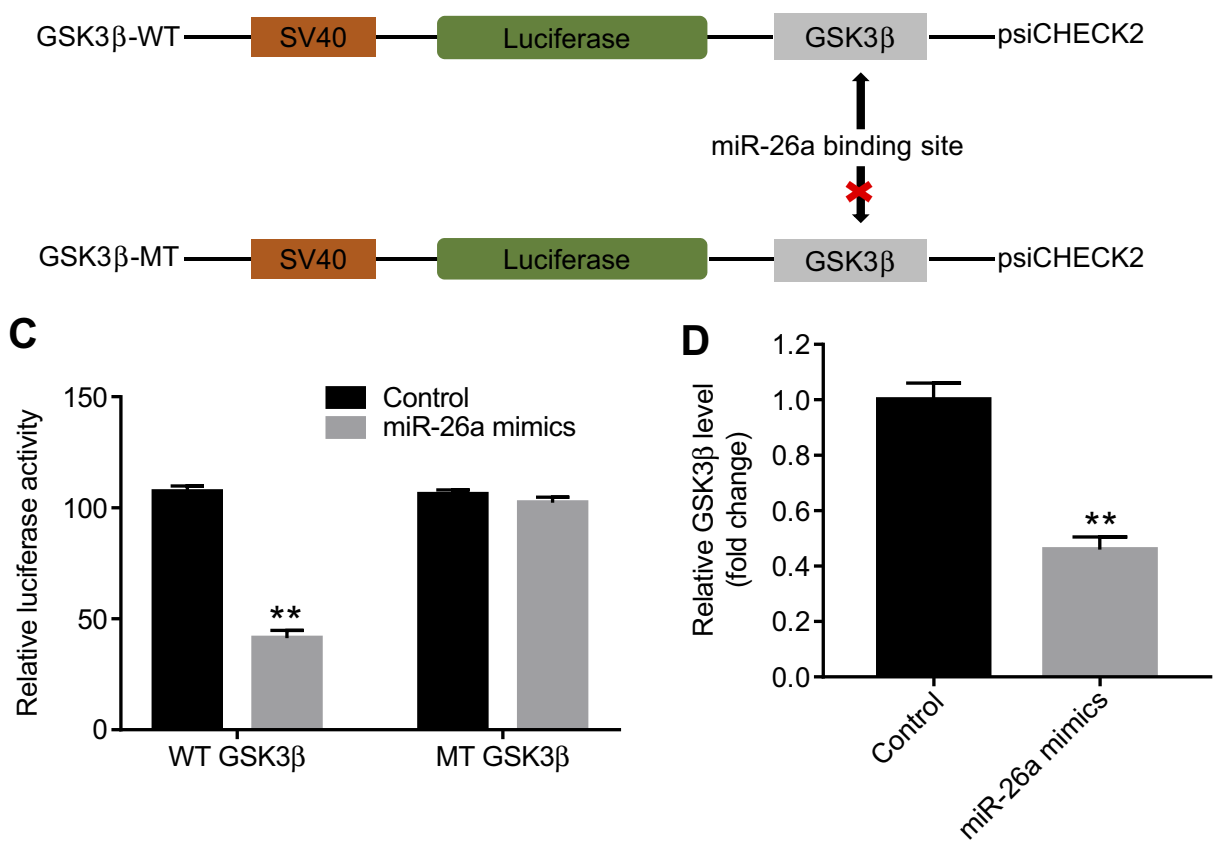

Figure 4 GSK3 $\beta$ was a direct target of miR-26a. (A and B) Gene structure of GSK3 $\beta$ at the position of $1604-1611$ indicates the predicted target site of miR-26a in its 3'UTR, with a sequence of UUACUUGAC. (C) The luciferase activity was measured by using the dual luciferase reporter assay. (D) MLTC-I cells were transfected with I0 nM miR-26a mimics for 24 hrs. Relative expression of GSK3 $\beta$ in MLTC-I cells was detected by qRT-PCR. **P<0.0I compared with control group. 

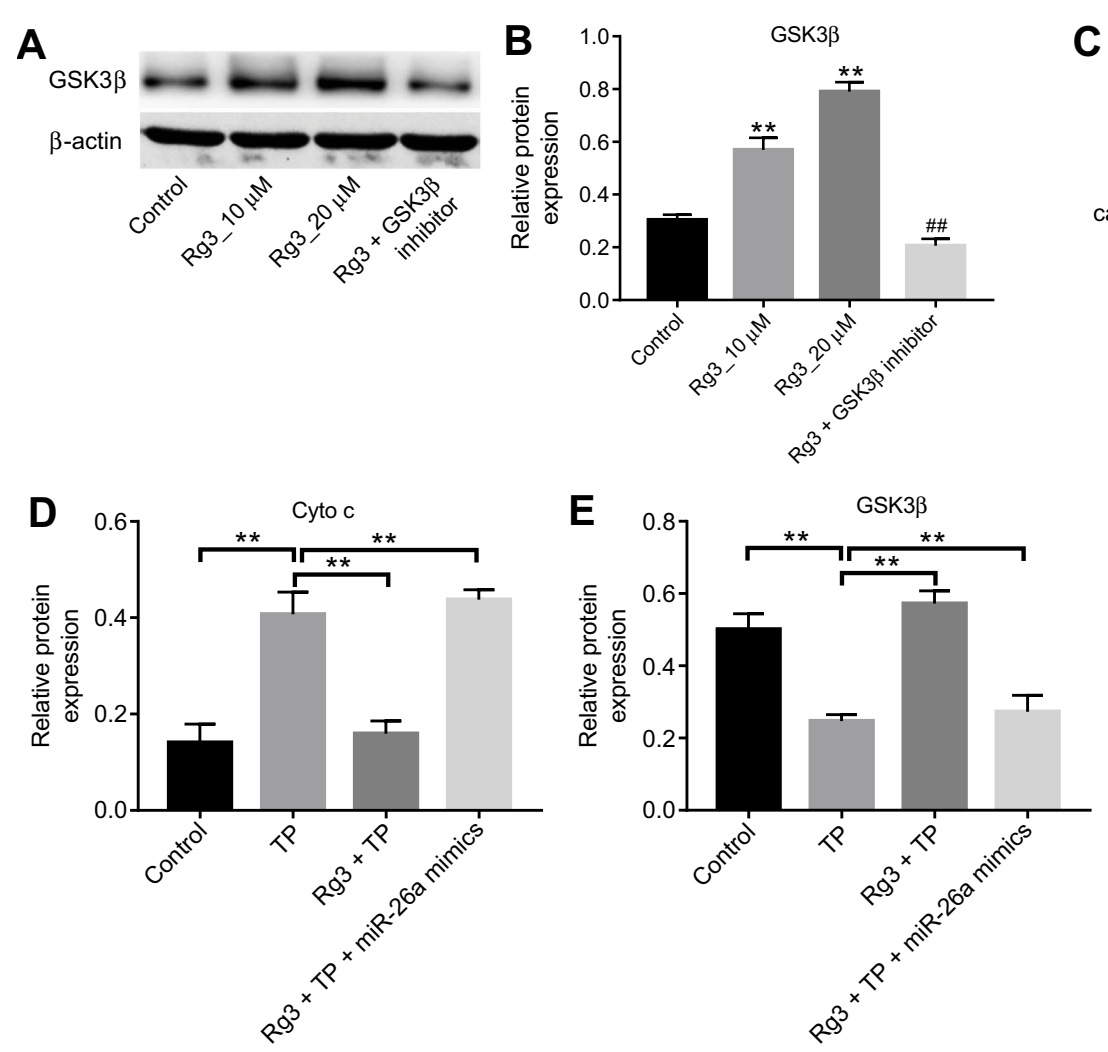
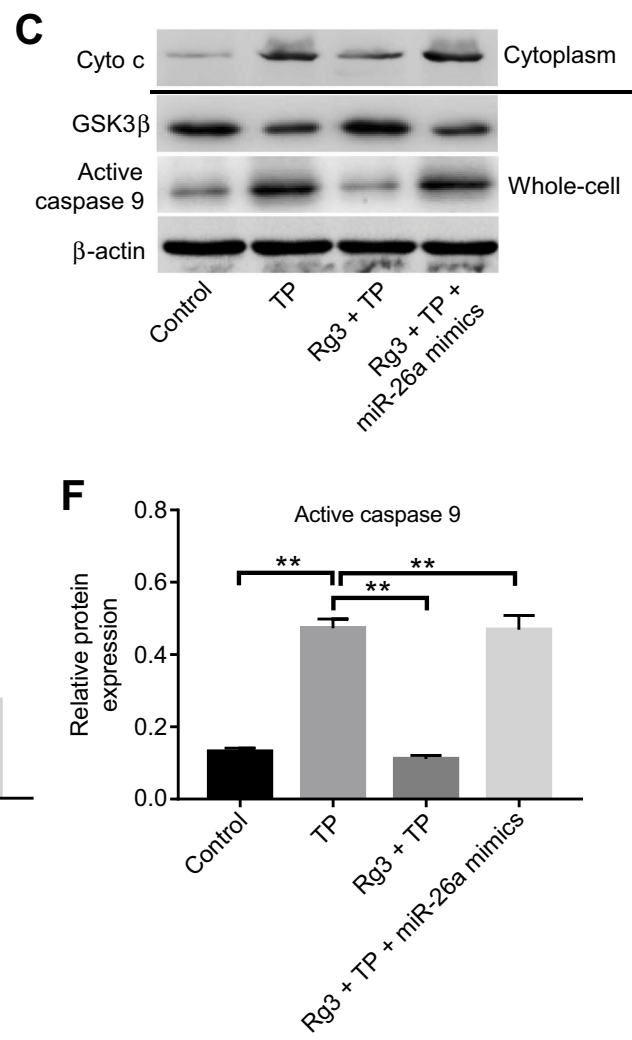

Figure 5 Overexpression of miR-26a reversed the protective effects of Rg3 against TP-induced cytotoxicity via targeting GSK3ß. (A and B) MLTC-I cells were treated with

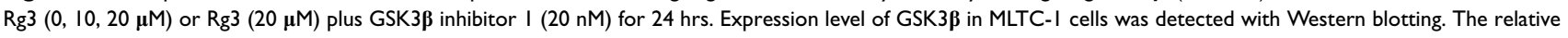
expression of GSK3 $\beta$ was quantified via normalization to $\beta$-actin. (C) MLTC-I cells were treated with $120 \mathrm{nM}$ TP $+20 \mu \mathrm{Mg} 3$ or/and miR-26a mimics for 24 hrs. Expressions of GSK3 $\beta$ and active caspase 9 in MLTC-I cells and the level of Cyto c in cytoplasm were detected with Western blotting. (D-F) The relative expressions of Cyto c, GSK3 $\beta$ and active caspase 9 were quantified via normalization to $\boldsymbol{\beta}$-actin. $* * P<0.01$ compared with control group; ${ }^{\#} P<0.01$ compared with $\mathrm{Rg} 3+\mathrm{TP}$ group.

and spermiogenesis. ${ }^{37}$ In this study, we found that TP significantly inhibited proliferation of MLTC-1 cells. However, the toxicity effect of TP on MLTC-1 cells was reversed by $\mathrm{Rg} 3$. Moreover, Rg3 could reverse TP-induced apoptosis in MLTC-1 cells via downregulating the levels of Bax, active caspase 3, Cyto c and active caspase 9, and upregulating the level of Bcl-2. Kopalli et al indicated that $\mathrm{Rg} 3$ could alleviate hyperthermia-mediated male infertility. ${ }^{38}$ Ginseng could protect fertility factors and testicular damage in immobilization stress-induced rats. ${ }^{39}$ Furthermore, ginseng could improve the quality of spermatozoa via inhibiting apoptosis in rats. ${ }^{40}$ Consistent with these studies, our results illustrated that $\mathrm{Rg} 3$ could attenuate TP-induced cytotoxicity in MLTC-1 cells.

It has been shown that a number of miRNAs have been considered as biomarkers for the diagnosis of male hypogonadism. ${ }^{41}$ MiRNAs are endogenous small RNAs, which play important roles in male hypogonadism and infertility. ${ }^{42} \mathrm{Ma}$ et al found that miR-26a-5p could regulate sperm apoptosis. ${ }^{33}$ In the present study, the level of miR-26a significantly downregulated in Rg3-treated MLTC-1 cells, while TP slightly upregulated miR-26a expression in MLTC-1 cells. These results indicated that the level of miR26a was regulated by Rg3 in MLTC-1 cells. However, the protective effects of $\mathrm{Rg} 3$ against TP-induced cytotoxicity in MLTC-1 cells were reversed following transfection with miR-26a mimics. Therefore, it can be suggested that miR26a could reverse the anti-apoptotic effects of $\mathrm{Rg} 3$ on MLTC1 cells. Taken together, our data indicated that $\mathrm{Rg} 3$ protects MLTC-1 cells against TP by downregulation of miR-26a.

However, there are no reports pointing out the cell targets of miR-26a on MLTC-1 cells. The luciferase reporter assay was used to confirm the downstream targets of miR-26a. In this study, the data demonstrated that GSK3 $\beta$ was the direct target of miR-26a. GSK3 $\beta$, a serine/threonine kinase, is involved in diverse cellular processes including protein synthesis, cell cycle, proliferation and cell apoptosis. ${ }^{42}$ Fei et al indicated that silencing of GSK3 $\beta$ could induce apoptosis in prostate cancer cells. ${ }^{43}$ Hongjin et al found that adrenomedullin inhibited apoptosis in mesenchymal stem cells via increasing of GSK $3 \beta{ }^{44}$ In addition, phosphorylated 


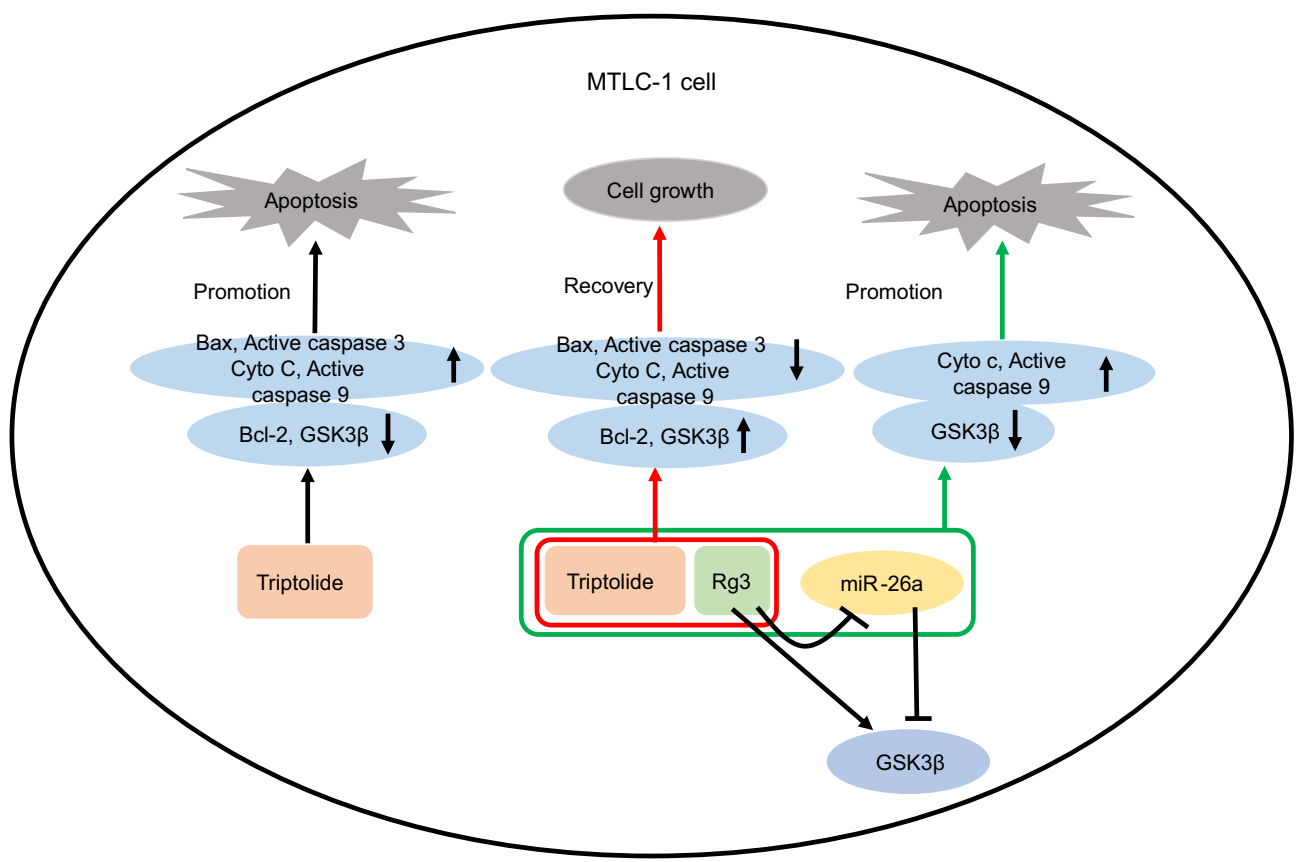

Figure 6 Overexpression of miR-26a reversed the protective effects of Rg3 against TP-induced cytotoxicity. TP significantly induced apoptosis in MLTC-I cells. However, $\mathrm{Rg} 3$ reversed TP-induced apoptosis in MLTC-I cells. In addition, overexpression of miR-26a reversed the protective effects of Rg3 against TP-induced cytotoxicity via targeting GSK3 $\beta$.

GSK3 $\beta$ could inhibit mitochondria-dependent apoptosis via decreasing the release of cytoplasmic Cyto-C and caspase 9. ${ }^{45}$ These reports demonstrated that GSK3 $\beta$ could inhibit cell apoptosis. ${ }^{46}$ As expected, in this study, $20 \mu \mathrm{M}$ Rg3 significantly increased the level of GSK3 $\beta$ in MLTC-1 cells. Therefore, we indicated that Rg3 attenuated TPinduced cytotoxicity in MLTC-1 cells via upregulation of GSK3 $\beta$, which was consistent with previous studies.

In addition, overexpression of miR-26a downregulated the level of GSK3 $\beta$ in MLTC-1 cells. Meanwhile, miR-26a mimics reversed the protective effects of Rg3 against TPinduced cytotoxicity via inhibiting the level of GSK3 $\beta$, and increasing the level of Cyto $\mathrm{c}$ and active caspase 9. These results illustrated that overexpression of miR-26a reversed the protective effects of $\mathrm{Rg} 3$ against TP-induced cytotoxicity via targeting GSK3 $\beta$ (Figure 6). Indeed, it is possible that $\mathrm{Rg} 3$ exerted protective effect against TP by regulating other pathways and more investigations are needed in the future.

\section{Conclusion}

In this study, we found that $\operatorname{Rg} 3$ exhibited markedly protective effects against TP-induced apoptosis in MLTC-1 cells. In addition, overexpression of miR-26a reversed the protective effects of $\mathrm{Rg} 3$ against TP-induced cytotoxicity via targeting GSK $3 \beta$. These findings indicated that $\mathrm{Rg} 3$ alleviated $\mathrm{TP}$-induced apoptosis in MLTC-1 cells via regulating GSK3 $\beta$. Therefore, Rg3 may serve as a potential agent for the treatment of male hypogonadism.

\section{Disclosure}

The authors report no conflicts of interest in this work.

\section{References}

1. Wu CY, Yu TJ, Chen MJ. Age related testosterone level changes and male andropause syndrome. Chang Gung Med J. 2000;23(6):348-353.

2. Chung HJ, Noh Y, Kim MS, et al. Steroidogenic effects of Taraxacum officinale extract on the levels of steroidogenic enzymes in mouse leydig cells. Anim Cells Syst (Seoul). 2018;22(6):407-414. doi:10.1080/19768354.2018.1453545

3. Yang F, Wei Y, Liao B, et al. Lycium barbarum polysaccharide prevents cisplatin-induced MLTC-1 cell apoptosis and autophagy via regulating endoplasmic reticulum stress pathway. Drug Des Devel Ther. 2018;12:3211-3219. doi:10.2147/DDDT.S176316

4. Gao F, Li G, Liu C, et al. Autophagy regulates testosterone synthesis by facilitating cholesterol uptake in Leydig cells. J Cell Biol. 2018;217 (6):2103-2119. doi:10.1083/jcb.201710078

5. Zhao J, Ren S, Liu C, et al. Di-(2-Ethylhexyl) phthalate increases obesity-induced damage to the male reproductive system in mice. Oxid Med Cell Longev. 2018;2018:1861984. doi:10.1155/2018/1861984

6. Ferlin A, De Toni L, Agoulnik AI, et al. Protective role of testicular hormone INSL3 from atrophy and weakness in skeletal muscle. Front Endocrinol (Lausanne). 2018;9:562. doi:10.3389/fendo.2018.00420

7. O'Reilly MW, Glisic M, Kumarendran B, et al. Serum testosterone, sex hormone-binding globulin and sex-specific risk of incident type 2 diabetes in a retrospective primary care cohort. Clin Endocrinol (Oxf). 2019;90(1):145-154. doi:10.1111/cen.13862 
8. O'Hara L, McInnes K, Simitsidellis I, et al. Autocrine androgen action is essential for leydig cell maturation and function, and protects against late-onset leydig cell apoptosis in both mice and men. Faseb J. 2015;29(3):894-910. doi:10.1096/fj.14-255729

9. Ni C, Fang Y, Chen X, et al. Stem Leydig cell regeneration in the adult rat testis is inhibited after a short-term triphenyltin exposure. Toxicol Lett. 2019;306:80-89. doi:10.1016/j.toxlet.2019.02.010

10. Tang M, Wang W, Cheng L, et al. The inhibitory effects of 20 (R)-ginsenoside $\mathrm{Rg} 3$ on the proliferation, angiogenesis, and collagen synthesis of hypertrophic scar derived fibroblasts in vitro. Iran J Basic Med Sci. 2018;21(3):309-317.

11. Choi KT. Botanical characteristics, pharmacological effects and medicinal components of Korean Panax ginseng C A Meyer. Acta Pharmacol Sin. 2008;29(9):1109-1118. doi:10.1111/j.17457254.2008.00789.x

12. Su X, Zhang D, Zhang H, Zhao K, Hou W. Preparation and characterization of angiopep-2 functionalized ginsenoside- Rg3 loaded nanoparticles and the effect on C6 glioma cells. Pharm Dev Technol. 2019;1-37. doi:10.1080/10837450.2018.1551901

13. Li X, Tsauo J, Geng C, et al. Ginsenoside Rg3 decreases NHE1 expression via inhibiting EGF-EGFR-ERK1/2-HIF-1 alpha pathway in hepatocellular carcinoma: a novel antitumor mechanism. Am J Chin Med. 2018;46:1-17.

14. Wang H, Wu W, Wang G, et al. Protective effect of ginsenoside Rg3 on lung injury in diabetic rats. J Cell Biochem. 2019;120:3323-3330.

15. Chen J, Liu GZ, Sun Q, et al. Protective effects of ginsenoside Rg3 on TNF-alpha-induced human nucleus pulposus cells through inhibiting NF-kappaB signaling pathway. Life Sci. 2019;216:1-9. doi:10.1016/j.1fs.2018.11.022

16. Lee WJ, Kim YS, Shim WS. Korean red ginseng extract and ginsenoside $\operatorname{Rg} 3$ have anti-pruritic effects on chloroquine-induced itch by inhibition of MrgprA3/TRPA1-mediated pathway. J Ginseng Res. 2018;42(4):470-475. doi:10.1016/j.jgr.2017.05.004

17. Liu T, Peng YF, Jia C, et al. Ginsenoside Rg3 improves erectile function in streptozotocin-induced diabetic rats. J Sex Med. 2015;12 (3):611-620. doi:10.1111/jsm. 12779

18. Cao Y, Ye Q, Zhuang M, et al. Ginsenoside Rg3 inhibits angiogenesis in a rat model of endometriosis through the VEGFR-2-mediated PI3K/Akt/mTOR signaling pathway. PLoS One. 2017;12(11) e0186520. doi:10.1371/journal.pone.0186520

19. Huynh PN, Hikim AP, Wang C, et al. Long-term effects of triptolide on spermatogenesis, epididymal sperm function, and fertility in male rats. J Androl. 2000;21(5):689-699.

20. Huang ZJ, Que HQ, Peng HY, et al. [Reproductive toxicity of triptolide and its mechanism in male rats]. Zhongguo Zhong Yao Za Zhi. 2015;40(23):4655-4659.

21. Hikim AP, Lue YH, Wang C, et al. Posttesticular antifertility action of triptolide in the male rat: evidence for severe impairment of cauda epididymal sperm ultrastructure. J Androl. 2000;21 (3):431-437.

22. Pardo M, Abrial E, Jope RS, Beurel E. GSK3beta isoform-selective regulation of depression, memory and hippocampal cell proliferation. Genes Brain Behav. 2016;15(3):348-355. doi:10.1111/gbb.12 283

23. Narasimhan G, Henderson J, Luong HT, et al. OBG-like ATPase 1 inhibition attenuates angiotensin II-induced hypertrophic response in human ventricular myocytes via GSK-3beta/beta-catenin signaling. Clin Exp Pharmacol Physiol. 2019. doi:10.1111/14401681.13101

24. Teng Y, Wang Y, Fu J, et al. Cyclin T2: a novel miR-15a target gene involved in early spermatogenesis. FEBS Lett. 2011;585 (15):2493-2500. doi:10.1016/j.febslet.2010.11.022

25. Li F, Wei H, Li H, et al. miR-26a prevents neural stem cells from apoptosis via beta-catenin signaling pathway in cardiac arrest-induced brain damage. Biosci Rep. 2019. doi:10.1042/ BSR20181635
26. Livak KJ, Schmittgen TD. Analysis of relative gene expression data using real-time quantitative PCR and the 2(-Delta Delta C(T)) method. Methods. 2001;25(4):402-408. doi:10.1006/meth.2001.1262

27. Umehara T, Kawashima I, Kawai T, et al. Neuregulin 1 regulates proliferation of leydig cells to support spermatogenesis and sexual behavior in adult mice. Endocrinology. 2016;157(12):4899-4913. doi:10.1210/en.2016-1478

28. Bouhallier F, Allioli N, Lavial F, et al. Role of miR-34c microRNA in the late steps of spermatogenesis. Rna. 2010;16(4):720-731. doi:10.1261/rna.1963810

29. Wu J, Bao J, Kim M, et al. Two miRNA clusters, miR-34b/c and miR-449, are essential for normal brain development, motile ciliogenesis, and spermatogenesis. Proc Natl Acad Sci U S A. 2014;111 (28):E2851-2857. doi:10.1073/pnas.1407777111

30. Presslauer C, Tilahun Bizuayehu T, Kopp M, Fernandes JM, Babiak I. Dynamics of miRNA transcriptome during gonadal development of zebrafish. Sci Rep. 2017;7:43850. doi:10.1038/ srep43850

31. Kasimanickam VR, Kasimanickam RK. Differential expression of microRNAs in sexually immature and mature canine testes. Theriogenology. 2015;83(3):394-398.e391.

32. Wu J, Bao J, Wang L, Hu Y, Xu C. MicroRNA-184 downregulates nuclear receptor corepressor 2 in mouse spermatogenesis. BMC Dev Biol. 2011;11:64. doi:10.1186/1471-213X-11-31

33. Ma J, Fan Y, Zhang J, et al. Testosterone-dependent miR-26a-5p and let-7g-5p act as signaling mediators to regulate sperm apoptosis via targeting PTEN and PMAIP1. Int J Mol Sci. 2018;19(4). doi:10.3390/ ijms 19041233.

34. Kang PC, Leng KM, Liu YP, et al. miR-191 inhibition induces apoptosis through reactivating secreted frizzled-related protein-1 in cholangiocarcinoma. Cell Physiol Biochem. 2018;49(5):1933-1942. doi:10.1159/000493654

35. Sun D, Dong W, Jin B, et al. Mechanisms of Yangjing Capsule in leydig cell apoptosis and testosterone synthesis via promoting StAR expression. Biol Pharm Bull. 2018;41(9):1401-1405. doi:10.1248/ bpb.b18-00205

36. Ma B, Qi H, Li J, et al. Triptolide disrupts fatty acids and peroxisome proliferator-activated receptor (PPAR) levels in male mice testes followed by testicular injury: a GC-MS based metabolomics study. Toxicology. 2015;336:84-95. doi:10.1016/j. tox.2015.07.008

37. Dhar P, Singla N. Histomorphological and biochemical changes induced by triptolide treatment in male lesser bandicoot rat, bandicota bengalensis. Pestic Biochem Physiol. 2014;116:49-55. doi:10.1016/j. pestbp.2014.09.009

38. Kopalli SR, Cha KM, Hwang SY, Jeong MS, Kim SK. Korean red ginseng (Panax ginseng Meyer) with enriched Rg3 ameliorates chronic intermittent heat stress-induced testicular damage in rats via multifunctional approach. J Ginseng Res. 2019;43(1):135-142. doi:10.1016/j.jgr.2018.06.004

39. Lee SH, Choi KH, Cha KM, et al. Protective effects of Korean red ginseng against sub-acute immobilization stress-induced testicular damage in experimental rats. $J$ Ginseng Res. 2019;43(1):125-134. doi:10.1016/j.jgr.2017.09.002

40. Eskandari M, Ghalyanchi Langeroudi A, Zeighami H, et al. Coadministration of ginseng and ciprofloxacin ameliorates epididymo-orchitis induced alterations in sperm quality and spermatogenic cells apoptosis following infection in rats. Andrologia. 2017;49(3). doi:10.1111/and.12621.

41. Procopio MS, de Avelar GF, Costa GMJ, et al. MicroRNAs in Sertoli cells: implications for spermatogenesis and fertility. Cell Tissue Res. 2017;370(3):335-346. doi:10.1007/s00441-017-2667-z

42. Bai JF, Wang YK, Wang P, et al. Uncovering male fertility transition responsive miRNA in a wheat photo-thermosensitive genic male sterile line by deep sequencing and degradome analysis. Front Plant Sci. 2017;8:1370. doi:10.3389/fpls.2017.01370 
43. Gao F, Al-Azayzih A, Somanath PR. Discrete functions of GSK3 $\alpha$ and GSK3 $\beta$ isoforms in prostate tumor growth and micrometastasis. Oncotarget. 2015;6(8):5947-5962. doi:10.18632/oncotarget. 3335

44. Si H, Zhang Y, Song Y, Li L. Overexpression of adrenomedullin protects mesenchymal stem cells against hypoxia and serum deprivation-induced apoptosis via the Akt/GSK3 $\beta$ and Bcl-2 signaling pathways. Int J Mol Med. 2018;41(6):3342-3352.
45. Kim JE, Lim JH, Jeon GS, et al. Extrinsic apoptosis pathway altered by glycogen synthase kinase-3beta inhibitor influences the net drug effect on NSC-34 motor neuron-like cell survival. Biomed Res Int. 2017;2017:4163839. doi:10.1155/2017/4163839

46. Yu J, Zheng J, Lin J, et al. Indirubin-3-oxime prevents $\mathrm{H} 2 \mathrm{O} 2$-induced neuronal apoptosis via concurrently inhibiting GSK3beta and the ERK pathway. Cell Mol Neurobiol. 2017;37(4):655-664. doi:10.1007/s10571-016-0402-z

\section{Publish your work in this journal}

Drug Design, Development and Therapy is an international, peerreviewed open-access journal that spans the spectrum of drug design and development through to clinical applications. Clinical outcomes, patient safety, and programs for the development and effective, safe, and sustained use of medicines are a feature of the journal, which has also been accepted for indexing on PubMed Central. The manuscript management system is completely online and includes a very quick and fair peer-review system, which is all easy to use. Visit http://www. dovepress.com/testimonials.php to read real quotes from published authors. 